\title{
Mobile Meat Puppetry? Ruined Infrastructures, Embodiment and Agency in Driving
}

\author{
Andrew Dawson \\ University of Melbourne, Melbourne, Australia \\ Email: dawsona@unimelb.edu.au
}

How to cite this paper: Dawson, A. (2018). Mobile Meat Puppetry? Ruined Infrastructures, Embodiment and Agency in Driving. Advances in Anthropology, 8, $1-9$.

https://doi.org/10.4236/aa.2018.81001

Received: November 18, 2017

Accepted: December 23, 2017

Published: December 26, 2017

Copyright $\odot 2018$ by author and Scientific Research Publishing Inc. This work is licensed under the Creative Commons Attribution International License (CC BY 4.0).

http://creativecommons.org/licenses/by/4.0/

\begin{abstract}
Contemporary automobilities research is replete with representation of a docile driver body or, as it is sometimes humorously described, a 'mobile meat puppet'. This emerges, largely from research on automobilities in 'Developed-World' contexts. Contrastingly, in this article, through ethnography of driving experiences in post-Socialist and post-war Bosnia I explore material grounds for an agential driver. In particular, I consider how the enduring and decaying road infrastructure of Socialist Yugoslavia provides a basis for senses of empowerment in relation to new ethnic-nationalist states that are often experienced as oppressive and controlling.
\end{abstract}

Keywords

Automobility, Driving, Infrastructure, Ruins, Embodiment, Agency, State

\section{Introduction}

Contemporary automobilities research is replete with representation of a docile driver body or, as it is sometimes humorously described, a 'mobile meat puppet'. This emerges, largely from research on automobilities in 'Developed-World' contexts. In contrast, in a series of recent publications I have explored driving and the driver's body in what might be described as the 'Second-World' context of post-Socialist and post-war Bosnia and Herzegovina. I have described how driving in Bosnia often facilities imaginings of home in which antithetical Yugoslav and ethno-national ideas of belonging are resolved into ideas of multiculturalism (Dawson, 2015). I have also described how sensory engagements in driving in Bosnia are often implicated in ameliorating feelings of post-Socialist and post-war unease (Dawson, 2017a). And, building on the latter, I have explored the theoretical roots of a tendency in automobilities research to wrongly 
represent driving as a sensorially disengaged experience, a tendency against which I write (Dawson, 2017b). Implicit within each of the above is an emphasis on an agential driver-a driver that is attuned and sentient (Dawson, 2017a), and who, as a kind of automobile flâneur (Dawson, 2015), engages sometimes in acts of resistance (Dawson, 2017a; Dawson 2017b). In this article I explore some of the material grounds for such agency. In particular, I consider how the enduring and decaying road infrastructure of Socialist Yugoslavia-the 'old' Yugoslavia-provides a basis for senses of empowerment in relation to new ethnic-nationalist states that are often experienced as oppressive and controlling.

\section{Mobile Meat Puppets in Theory and Practice}

Research, especially of the state sponsored variety, on transport is characterised by an overriding concern to produce knowledge that informs interventions designed to regulate and optimise the bodily capacities of travellers to move efficiently and safely (Bonham, 2006). Representation of a docile driver's body is no more extreme than in the work of John Urry, the leading scholars of the automobilities turn in the contemporary social sciences. For Urry cars are "iron cages" (Urry, 2006: 22) into which the driver is "(s) trapped" [my emphasis] (Urry, 2006: 23) such that her body becomes "disciplined to the machine" (Urry, 2006: 23) and, given the above, to the state too presumably.

New automobile technologies-from those within the car through to those of the wider traffic infrastructure-are key in this respect. Transport Engineers with whom I increasingly collaborate describe themselves humorously, but not at all inaccurately as being in the business of producing 'mobile meat puppets'. Indeed, current excitement within this community generated by the advent of the autonomous vehicle seems to be based almost as much on the opportunity for relegating the 'irritating' human factor in research and development as it is on possibilities for new income streams and innovation. Furthermore, and moving beyond engineers, the puppet is an especially apt metaphor for how social scientific scholars of automobilities have tended to represent the driver, since the sub-field's inception and through to the present day.

Early automobilities research in the social sciences cannot be separated from the Marxian critique of Capitalist modernity, whose quintessential productive form is, of course, Fordism. The 'auto' in automobility is multi-vocal. It speaks simultaneously to the mechanical capacity for independent movement and to the independence of human action. The connection between each is familiar to most of us, at least in the 'West', via the genres of the road song, novel and movie. However, for Marxian scholars such as Henri Lefebvre (1971), the 'appearance' of freedom that automobility enabled was, essentially deleterious. The idea of the 'freedom of the road' functioned primarily for the interests of capital-it was an expression of bourgeois individualism and, in turn, the privatized consumer. It undergirded the growth of suburbia, that most alienating locus of human life. And, most importantly, it ideologically disguised processes of control. Part of the 
fascination of the marionette is our awareness that its apparent autonomy is, in fact, illusory.

Fast-forward to the present. Cutting-edge automobilities research is dominated, increasingly by actor-network theory. The genre considers, in part how new automobile technologies unsettle the erstwhile boundaries between drivers, cars and traffic infrastructures. The result is the emergence of new person-thing ontologies (Katz, 2000: 33). Having said this, energy is still devoted to uncovering where agency primarily lies in the driver-car-infrastructure 'assemblage'. More often than not it is attributed to infrastructure and, thereby more often than not too, to the state. As leading automobilities scholar Mimi Sheller describes:

"If human bodies are being transformed by new technologies that seek to hybridize and effectively share agency, then the most significant and rapid transformations are taking place not at the scale of the individual body-in-the-car but at the level of the driver-car-software hybrid's interaction with systems of pervasive and embedded computing, surveillance and code-sorting that are automating, re-shaping and displacing to multiple scales and actants the wider movement-space of automobility (Sheller, 2007: 177).

A further part of the fascination of the marionette is, clearly the connective strings and levers that enable its illusory autonomy, and that lead back ultimately to the puppet-master(s).

\section{Infrastructure and Ruination}

The image of the driver as mobile meat puppet emerges from research on driving in, and on the basis of the development of automobile technologies and infrastructures for, largely, the 'Developed-World'. However, what of other contexts-of underdevelopment, human and natural disaster, or rapid transition-especially those characterised by 'ruination'?

In Imperial Debris: Reflections On Ruins and Ruination (2008) Anne Stoler writes against the commonplace depiction of ruins as the desolate material remains of social and political formations long since disappeared-Angkor Wat and its like. Instead, she draws attention to how ruins often remain as "tenacious trace(s)" (Stoler, 2008: 196) of said formations, "that weigh on the future and shape(s) the present" (Stoler, 2008: 194). While ruins may be non-human, taking the form of defunct infrastructures for example, they may also be human, like the mentally ill, sick and homeless subjects produced by successively neglectful political regimes and dumped in Brazil's 'zones of abandonment' (Biehl, 2005). Most importantly, as Stoler highlights, ruins always have an oxymoronic character-while they endure they also decay.

Stoler's concern is principally with the ruins of imperialism. However, she notes that the ruins of other social and political formations, such as Modernity 
(see, for example, Szmagalska-Follis, 2008) have a similar tenacity. Bosnia, the site of my own research, is characterised by the co-presence of several intersecting historic social and political formations in which the ruins of one remain within others. I highlight what are, almost certainly the two must salient such intersections of historic social and political formations.

i) The rural within the urban.

Following World War II Bosnia underwent a process of massive urbanisation. This was designed by the post-war Socialist state, partly with the aim of ameliorating ethnic conflict. In contrast to village traditions of ethnic endogamy, amongst Croats, Muslims and Serbs alike, cities would be places for mixed marriage and, thus for forging a pan-ethnic Yugoslav identity. However, and especially because of the rapidity of the process of urbanisation, equalled in the era only by Greece amongst European nations (Glenny, 2014), Bosnia's urbanity is vulnerable. There is, as Slavenka Drakulić describes, always a pervasive sense of "soil rising from beneath the asphalt" (Drakulić, 2001: 11). Indeed, enduring traces of the rural re-emerge easily, as Van der Port so brilliantly describes, from within the psyches of urban people... with the lubrication of a little Gypsy music and alcohol of course (Van der Port, 1999). And, as Ramet makes clear in the title of a much celebrated article, the Bosnian War of 1993-96 that brought ethnic division back to the country's cities, such as Sarajevo was, at least in part an outcome of 'nationalism and the 'idiocy' of the countryside' (Ramet, 1996).

ii) Yugoslavia with in ethnic-nationalism.

The Bosnian War involved wide-scale processes of ethnic cleansing and domicide (Porteous \& Smith, 2001), whereby much of the built environment was destroyed, rendering landscapes of home (Dawson \& Johnson, 2004) meaningless so as to prevent the return of displaced persons. In the post-war era the country is governed by a Bosnian nation state and three ethno-nationally dominated official or unofficial statelets (1), or 'entities' as they are called, to which powers are significantly devolved. Inevitably in this context, the empty spaces rendered by domicide are filled increasingly by the materialities of the new ethnic-nationalisms.

However, as Brian Larkin describes, large-scale infrastructure-in the forms of electrical plants, railroads, media installations and the like-are a most effective means by which states inscribe themselves in the subjectivities of their citizens (Larkin, 2008). In Bosnia the process of urbanization initiated by the post-World War II Socialist Yugoslav state was accompanied by a massive program of infrastructural development. Contrastingly, in the post-Socialist and post-Bosnian War era of market Capitalism responsibility for renovation of profitable infrastructure falls increasingly to private and overseas investors, and for unprofitable infrastructure to the Bosnian state and the entities. However, faced by enormous budget deficits, like post-war states the World over, the Bosnian state and the entities are ill-equipped to do the work of renovation and, thus to effectively ethno-nationalise infrastructure. 
Bosnia's automobile system is a most visible manifestation of this state of affairs. An increasingly ethno-nationalised landscape is traversed by enduringly Yugoslav roads. More than a mere trace, Bosnia's roads are a reminder of the power of the old Yugoslavia in all its ruined tarmacadam and concrete obduracy.

In what follows I consider, albeit in light ethnographic detail, driving experiences of Yugoslav identifying people in Bosnia. Though typical of many people from the multi-ethnic city of Tuzla where I conducted the research, such people are often referred to pejoratively as 'Yugonostalgics' (see also Palmberger, 2008). In Serbo-Croat the term holds all of the pathological connotations implicit in the original meaning of nostalgia-a malady borne of the experience of rupture (Starobinski, 1966). They are, in a sense rendered, like João Biehl's informants in Brazil's zones of abandonment, human ruins of a defunct social and political formation (Biehl, 2005).

For Yugonostalgics the rise of ethnic-nationalism is often experienced as emanating from the state, and flowing progressively through to one's private life, especially as loved ones and even ones selves begin to ethno-nationally identify. Often too this is experienced as entailing loss of agency, as Yugoslav ways of being are increasingly proscribed. In extreme that loss of agency can also involve loss control of one's body (Sofos, 1996).

In this context, driving-in the almost uniquely private space of the car-is represented often as escape. However, in her wonderful ethnography of West Bank partition Amahl Bishara suggests how driving, a 'technique of the body' as Mauss might have had it, may be significant in more visceral ways (Bishara, 2015). To give just one example, Bishara illuminates how the checkpoints that restrict movement and the rush-inducing checkpoint-avoiding U-turns that re-enable it are, respectively key bodily forms of state control and resistance against it (Bishara, 2015). Elsewhere, I have linked such experiences to matters of technological ruination. The skilful endeavour of wrestling with the failing mechanics of decrepit cars is felt by some Yugoslav identifying women as entailing bodily integrity, in the face of the state control of their reproductive organs (Dawson, 2017a: 8-10). In what follows I explore connections between infrastructural ruins-their endurance and their decay-and senses of agency amongst Yugoslav drivers, especially as they relate to the rise of the ethno-nationalist state.

\section{Enduring and Decaying Infrastructures, Embodiment and Agency}

Endurance of the 'old' Yugoslavia within the roads infrastructure is evident at a number of levels. It is within signage. The roads are replete with fading red stars, logos for now defunct state enterprises and the like. It is also within nomenclature. For example, Yugoslavia's most significant of infrastructure projects was, arguably its main highway. People continue to use its original name, the 'Highway of Brotherhood and Unity'. This refers to the foundational policy of federalism, with 'brotherhood' denoting the equality of nations and 'unity' the con- 
necting Yugoslav ideal. Furthermore, like other roads in the former-Yugoslav space, the remains of the highway are dotted with, often vast Socialist monuments. Built in the context of the Yugoslav state's memory policy (Denich, 1994), many of these mark and 're-remember' sites of ethnic conflict between Croats, Muslims and Serbs in World War II as, instead, places of victory by the Proletariat over the Bourgeoisie in a class war.

However, ideologically instilling Yugoslavia (and forgetting ethnic-national difference and conflict) through infrastructure not only worked at the 'soft' levels of monuments, signage and nomenclature, but also at the material level of the movement of bodies through space. Ethnic-nationalist movement was curtailed. For example, again Denich demonstrates how the layout of roads was designed in order to avoid and, thus forget some sites of ethnic conflict in World War II, places that might otherwise have become contexts for ethnic-national martyrdom, organisation and conflict (Denich, 1994). Conversely, of course, Yugoslavist movement was enabled. Most obviously, for example, despite its questionable effectiveness (see, for example, Pozharliev, 2016), the Highway of Brotherhood and Unity that ran from Slovenia to Macedonia through Croatia and Serbia, and skirting Bosnia along the way had the effect of uniting previously antithetical nations in one space of Yugloslav automobility.

Importantly, these processes of ethnic-nationalist mobility curtailment and Yugoslavist mobility enablement remain. For example, here is how Darko, a Yugoslav-identifying Serb informant described his journeys to me. Darkohad been compelled by diminishing employment opportunities in increasingly Islamicized Tuzla to move to Banja Luka, the de facto capital of the Serbian entity in Bosnia. His job involved meeting with suppliers in Beograd, the capital of Serbia proper. In the new era of ethnic-nationalism infrastructures ought to have been built better to connect Banja Luka to Beograd, a city with which the Serbian entity in Bosnia was increasingly enmeshed, both politically and economically. However, Darko explained, a journey that could potentially be a mere $200 \mathrm{~km}$ through contiguous Serbian territory actually involves driving almost $300 \mathrm{~km}$ through three sovereign nation-states, and along the remnants of the Highway of Brotherhood and Unity. Having said this, Darko's irritation at the journey's length was counterbalanced by a sly pleasure he derived from conceptualising it as indicative of the failings and endurances of contemporary state ethnonationalism and historic state Yugoslavism respectively. In a laconic and sarcastic manner not untypical of Yugoslav men of his age (see, for example, Jansen, 2008), he shrugged his shoulders and laughed, "ha... what can we do. Yugoslavia worked. Still works. The new way is fucked."

More than mere long excursions, Darko described how his journeys could sometimes be slowed to a matter of days, not only by the whims of states and their border guards, but by the decaying infrastructure. Much of the route was a mess of potholes, faded road-markings, broken-downtraffic-lights, and certainly an absence of anything resembling the kinds of 'Intelligent Transport Systems' 
that are more typical in the 'West'. A notable exception was the occasional hand-held speed camera whose sole purpose was, so Darko suggested, to provide extra household income for the traffic police.

Such conditions make for explicit collaboration between drivers. As Darko explained, "everybody knows to flash your headlights to warn of the police." And, more importantly, the decaying infrastructure appears to give onto a kind of collaboration that is more bodily rooted. As Mirsad, a Yugoslav-identifying informant put it while allaying my fears about oncoming traffic: "calm down comrade... he knows that I expect him to slow down...he knows that he ought to slow down... we might be divided in many ways, but underneath it all we are all the same...these roads are still in our bones" (Dawson, 2017a: 13). Driving is a practice governed by locally shared rules that are un-reflexive (Thrift, 2004). In turn, traffic can be experienced as like a community based on embodied knowledge (Dawson, 2017a), and movement on the roads a kind of choreography (Thrift, 2004). In Bosnia, where ruins rather than new infrastructures dominate the automobile landscape, such knowledge comes particularly to the fore. Importantly, emerging from automobility in the Socialist era, it is a pan-ethnic knowledge (Dawson, 2017a). Thus, driving on Bosnia's ruined roads entails, then, in many ways a profoundly bodily experience of persisting Yugoslav communality (Dawson, 2017a).

\section{Conclusion}

Building on Stoler's insights on ruination (2008) and transposing them from post-Imperial to post-Socialist contexts, in this article I have explored ruined infrastructure from past social and political formations as material grounds for contemporary forms of agency. In particular, I argue that within the context of Bosnia the enduring and decaying road system from the 'old' Yugoslavia provides a basis for empowerment in relation to new ethnic-nationalist states that are often experienced as oppressive and controlling.

Roads and the driving of them are often represented as producing docile bodies (or 'meat puppets'). This may often be the case in places where research that draws this conclusion is based, the Developed-World, replete with its modern transport infrastructures. It is less so the case in places like Bosnia, where infrastructure is more often than not in a state of ruination.

\section{Note}

(1) Bosnia is divided by the official 'entities' of The Federation of Bosnia and Herzegovina, which is ethnically mixed, but Muslim dominated, and Republika Srpska, which has an overwhelming Serb majority. Additionally, there is the unofficial and Croat dominated entity of Herzeg-Bosnia.

\section{References}

Biehl, J. (2005). Vita: Life in a Zone of Social Abandonment. Berkeley: University of Cali- 
fornia Press.

Bishara, A. (2015). Driving While Palestinian in Israel and the West Bank: The Politics of Disorientation and the Routes of a Subaltern Knowledge. American Ethnologist, 42, 33-54. https://doi.org/10.1111/amet.12114

Bonham, J. (2006). Transport: Disciplining the Body that Travels. Sociological Review, 54, 57-74. https://doi.org/10.1111/j.1467-954X.2006.00637.x

Dawson, A. \& Johnson, M. (2004). Migration, Exile and Landscapes of the Imagination. In S. Cairns (Ed.), Drifting: Architecture and Migrancy (pp. 116-128). London and New York: Routledge.

Dawson, A. (2015). The Road to Srebrenica: Automobility and Belonging in a Post-Socialist/War Milieu. Anthropological Notebooks, 21, 5-25.

Dawson, A. (2017a). Driven to Sanity: An Ethnographic Critique of the Senses in Automobilities. The Australian Journal of Anthropology, 28, 3-20.

https://doi.org/10.1111/taja.12168

Dawson, A. (2017b). Why Marx was a Bad Driver: Alienation to Sensuality in the Anthropology of Automobility. Advances in Anthropology, 7, 1-16. https://doi.org/10.4236/aa.2017.71001

Denich, B. (1994). Dismembering Yugoslavia: Nationalist Ideologies and the Symbolic Revival of Genocide. American Ethnologist, 21, 367-390. https://doi.org/10.1525/ae.1994.21.2.02a00080

Drakulić, S. (2001). Café Europa: Life after Communism. New York: Penguin Books.

Glenny, M. (2014). The Balkans: Nationalism, War and the Great Powers, 1804-2012. New York: Penguin Books.

Jansen, S. (2008). Misplaced Masculinities: Status Loss and the Location of Gendered Subjectivities Amongst 'Non-Transnational' Bosnian Refugees. Anthropological Theory, 8, 181-200. https://doi.org/10.1177/1463499608090790

Katz, J. (2000). How Emotions Work. Chicago: Chicago University Press.

Larkin, B. (2008). Signal and Noise: Media, Infrastructure and Urban Culture in Nigeria. Durham and London: Duke University Press. https://doi.org/10.1215/9780822389316

Lefebvre, H. (1971). Everyday Life in the Modern World. Rabinovitch, S., Trans. London: Allen Lane.

Palmberger, M. (2008). Nostalgia Matters: Nostalgia for Yugoslavia as Potential Vision for a Better Future. Sociologija. Časopis Zasociologiju, Socijalnu Psihologijui Socijalnu Antropologiju, 50, 355-370. https://doi.org/10.2298/SOC0804355P

Porteous, J. D., \& Smith, S. E. (2001). Domicide: the Global Destruction of Home. Montreal \& Kingston: McGill-Queen's University Press.

Pozharliev, L. (2016). Collectivity vs. Connectivity: Highway Peripheralization in Former Yugoslavia (1940s-1960s). Journal of Transport History, 37, 194-213.

https://doi.org/10.1177/0022526616667134

Ramet, S. P. (1996). Nationalism and the 'Idiocy' of the Countryside: The Case of Serbia. Ethnic and Racial Studies, 19, 70-87. https://doi.org/10.1080/01419870.1996.9993899

Sheller, M. (2007). Bodies, Cybercars and the Mundane Incorporation of Automated Mobilities. Social and Cultural Geography, 8, 175-197. https://doi.org/10.1080/14649360701360063

Sofos, S. (1996). Inter-Ethnic Violence and the Gendered Construction of Ethnicity in Former Yugoslavia. Social Identities, 2, 37-72. https://doi.org/10.1080/13504639652394

Starobinski, J. (1966). The Idea of Nostalgia. Diogenes, 54, 81-103. 
https://doi.org/10.1177/039219216601405405

Stoler, A. (2008). Imperial Debris: Reflections on Ruins and Ruination. Cultural Anthropology, 23, 191-219. https://doi.org/10.1111/j.1548-1360.2008.00007.x

Szmagalska-Follis, K. (2008). Notes on Restoration and Redemption in Ukraine's Western Borderland. Cultural Anthropology, 23, 329-360.

https://doi.org/10.1111/j.1548-1360.2008.00011.x

Thrift, N. (2004). Driving in the City. Theory, Culture and Society, 21, 41-59. https://doi.org/10.1177/0263276404046060

Urry, J. (2006). Inhabiting the Car. Sociological Review, 54, 17-31. https://doi.org/10.1111/j.1467-954X.2006.00635.x

Van der Port, M. (1999). It Takes a Serb to Know a Serb: Uncovering the Roots of Obstinate Otherness. Critique of Anthropology, 19, 7-30.

https://doi.org/10.1177/0308275X9901900104 